\title{
The Relationship between Level of Architect's Professional Competencies and Client Satisfaction Level
}

\author{
Samuel Amos-Abanyie ${ }^{1}$, Edward Ayebeng Botchway ${ }^{1} \&$ Titus Ebenezer Kwofie $^{1}$ \\ ${ }^{1}$ Department of Architecture, Kwame Nkrumah University of Science and Technology, Kumasi, Ghana \\ Correspondence: Titus Ebenezer Kwofie, Department of Architecture, Kwame Nkrumah University of Science \\ and Technology, Kumasi, Ghana. Tel: 233-24-472-1622. E-mail: teeagk@yahoo.co.uk; \\ tekwofie.cap@knust.edu.gh
}

Received: July 15, 2014 Accepted: August 4, 2014 Online Published: October 26, 2014

doi:10.5539/emr.v3n2p10 URL: http://dx.doi.org/10.5539/emr.v3n2p10

\begin{abstract}
Identifying key competencies and how they relate to crucial outcomes such as client satisfaction has become a dominant area receiving intensive attention through research in recent times in organisational management, services consulting and construction. The evaluation of the link between client satisfaction and competencies is considered crucial to the success of consulting assignments in today's sophisticated, large-scale, risky and adversarial construction project environment. Yet the relationship between the competencies of the project team and the satisfaction level of clients has rarely been examined on professional architects in the construction industry. The objective of this study is to examine the relationship between the professional competencies of architects and client satisfaction level in the Ghanaian construction industry. Using a combined multiple regression and Pearson correlation analysis on survey data, the findings reveal a strong positive relationship between design and management competencies of architects and client satisfaction level with design competencies being a greater predictor of client satisfaction level. The results offer foundation for architects' continuous professional development and training towards performance improvement.
\end{abstract}

Keywords: client satisfaction, architects' competencies, design and management competencies, construction project delivery

\section{Introduction}

Client satisfaction (CS) is considered as an important factor in the development of the construction process in engineering and building consulting (Ofori, 1999; Torbica \& Stroh, 2001). Against this, attaining an acceptable level of client satisfaction has been considered extremely critical to the continued survival and economic stability of consulting business in today's competitive service market (Tang et al., 2003; Yang \& Peng, 2006). According to Escrig-Tena and Bou-Llusar (2005) and Prastacos et al. (2005), competitive advantage in today's industry can be ensured only by particular mutually coordinated competencies that correspond to professional, organizational and team strategy that maximises their outcomes. In mainstream human resource genre, client satisfaction and skills development have been seen as a sure way that effectively utilise employee skills in the workplace towards superior outcomes (Ley \& Albert, 2003). This approach has also been engendered as a viable means towards identifying and validating efficient managerial skills, professional practices, behaviours and development of requisite skills and knowledge that can generate the needed performance in organisations for enhanced results and client satisfaction (Tang et al., 2003; Yang \& Peng, 2006).

Conversely, though client satisfaction has been a topical issue in several studies in the construction industry, the main focus has been on assessing the satisfaction related to the product outcome and the performance of the project manager and contractors (Ng \& Chow, 2004; Yang \& Peng, 2006; Yang \& Zhu, 2006). Similarly, despite the emphasis that selection of competent architect is vital to project success that ensures client satisfaction (Cheung et al., 2002); empirical studies are yet to explore the link between the competencies of the architects and client satisfaction level in the construction industry. Given the extent and nature of critical roles architects play in construction project delivery as well as their direct influence on clients' needs and expectations in the construction industry should generate more interest in research by analysing the competencies and skills that influence client satisfaction level from both local and global perspective. Hence this study aims at examining the relationship between architects' competencies and client satisfaction level in the Ghanaian construction industry. 
The findings from this study is very crucial towards engendering the needed managerial and professional effectiveness needed in construction project delivery especially in Ghana and other developing countries. It is also anticipated that the knowledge and understanding of the key skills and competencies of architects that relate to client satisfaction will be very useful in the engagement of architects for consultancy services, their selection, performance evaluation and their continuous professional development in the construction industry.

\section{Literature Review}

\subsection{Client Satisfaction and Knowledge Consulting}

The services required of architects by clients are both professionally and technically inclined. In contrast, evaluating the competencies and performance of architects' services to meet the needs and expectations of the client will provide essential benefits that enables them to appraise the services received and to offer critical feedbacks that are necessary to stimulate the needed performance improvement in the services and behavioural competency. According to Alvesson (2001), professional service based consulting and engagements are knowledge-intensive and thus providers of such services must be client specific, designed to achieve the client's unique needs and optimum satisfaction. It is also deemed very crucial for them to exhibit precise skills and competencies toward performance of tasks that meets clients' needs and requirements to generate the desired satisfaction (Haverila et al., 2011). Empirically, studies have indicated that the essential reason for client satisfaction and acceptance of product and service outcome is rooted in the concept of perceived quality (Gottlieb et al., 1994). Typically, in product and service delivery, often several factors contribute to attaining the services delivery level that will result in the needed client satisfaction for full acceptance of the service outcome (Bennett et al., 2005). Also, in the context of construction services consulting, clients consider competencies and experience as significant factors that relate to the actual service outcome quality in meeting their satisfaction and often does form the basis of team composition and selection (Day \& Barksdale, 2003; Haverila et al., 2011).

Bennett et al. (2005) further espouse that tacit and explicit knowledge that is exhibited in the competencies of the professionals in performing the tasks that meet client needs and satisfaction is a prerequisite and thus must be rigorously pursued. In emerging literature, client satisfaction has been considered as being important for evaluating the performance outcome of service based tasks towards behaviour development and improvement in construction projects (Tang et al., 2003; Yang \& Peng, 2006). It can be contended that in architectural service engagement, the client remains the first and most significant appraiser of the quality of service and performance of the architect engaged. Hence full knowledge and understanding of the relationship between the client satisfaction level and the task behaviours of the architect is extremely useful to enable architects to apply themselves towards attaining the needed proficiency and performance levels necessary to meet the expectations of their clients.

\subsection{Architects' Professional Competencies}

Architects are expected to exhibit acceptable standards of professionalism, integrity, skills and aptitudes that are essential to the sustainable development of the built environment and the welfare of their societies and cultures in order to be considered competent in practice (UIA, 1999). They must possess a systematic body of knowledge, skills and theory developed through education, graduate and post-graduate training and experience that must assure their clients of acceptable standards enabling acceptable performance (UIA, 1999; AACA, 2008). In contrast, the challenge has been what constitutes the term competency? From literature, competency assumes contextual meaning across different disciplines and fields of management (Pickett, 1998; Moore et al., 2002). In the context of this study, the term has been used to refer to the cognitive and contextual abilities, behaviours and skills exhibited by task performers to motivate enhanced performance outcome level (Moore, Cheng \& Dainty, 2002). The obvious challenge has been what constitutes architects' professional competencies? Besides, the ever varying and changing expectations and needs of clients make it extremely difficult for architects and other construction professionals to remain competitive and excel at the same level of competencies in the industry (Ofori, 1999; Ling, 2003). As the construction industry grows and becomes increasingly competitive, multi-disciplinary and coupled with interdependent project environment, project success by emphasising on client satisfaction will largely and undoubtedly depend on the competencies of the project participants in meeting client expectations.

One of the biggest challenge in the Ghanaian construction industry (GCI) and other developing countries is high level unprofessionalism and managerial inefficiencies (Ahadzie \& Amoa-Mensah, 2010). In comparison, the issue of professionalism has become a topical issue in several professions such as teaching, accountancy, medicine, engineering and architecture. Currently in Ghana, emerging innovations in technology and constantly evolving variations in client needs have led to the Ghana Institute of Architect (GIA) to introduce continuous 
professional development (CPD) as a viable option for improving and equipping professionals with emerging skills critical towards efficient delivery of acceptable standards to meet client goals. According to the Architects' Registration Council of Ghana (ARC), architects must possess and exude tacit knowledge and skills that effectively perform the design requirements of their clients as well as acceptable management skills to oversee the construction of the design to meet client need in order to be considered professionally competent for acceptance onto the practising register. Generally, architects provide objective expert advice to client by applying cognitive ability, job knowledge, task proficiency, job experience, conscientiousness, initiative, social skills, controllability and commitment to offer the best of professional service to client as these forms the solid foundation in their selection for architectural services (Ling, 2003).

Many professional and regulatory bodies in architectural practice continue to set out and emphasize the benchmark standards of competencies against which professional practising architects should acquire, maintain and ensure continuous development towards highest standard practice (Royal Institute of British Architects (RIBA); Architects Accreditation Council of Australia (AACA); Ghana Institute of Architects (GIA); Commonwealth Association of Architects (CAA); American Institute of Architects (AIA)). It is asserted that competency is context-bound, visible, changeable, and must be connected to task activities and requires learning and development process (Biemans et al., 2004). Unfortunately, few studies (Cheung et al., 2002; Ling, 2003) tend to focus on the competency development of architects.

Drawing on the requirements from notable professional regulatory bodies in Architecture, Design and Management competencies remain the main tenets of professional competencies required for architectural practice to engender the needed performance to meet client expectations and delivery successes (AACA, 2008; RIBA, 2013). The design and management skills in professional practice is thus considered critical for the discrete activity that a competent architect must be able to perform to motivate the performance level required to meet client goals (AACA, 2008; Cheung et al., 2002). The design competencies refer to the skills and knowledge applied in the design process to evolve a design product that meets both regulatory requirements and technical soundness. Management competencies on the other hand include the managerial concepts, skills and proficient knowledge necessary to successfully manage, control, monitor, evaluate and deliver the product from the design. Given that architects' professional competencies relate to crucial performance outcomes that meet clients' needs and satisfaction, skills and knowledge development towards being efficient and deliver superior performance will be beneficial.

From the review and the main concepts identified, the perceived relationship between architects professional competencies and client satisfaction can be theoretically conceptualised in a framework as presented in Figure 1.

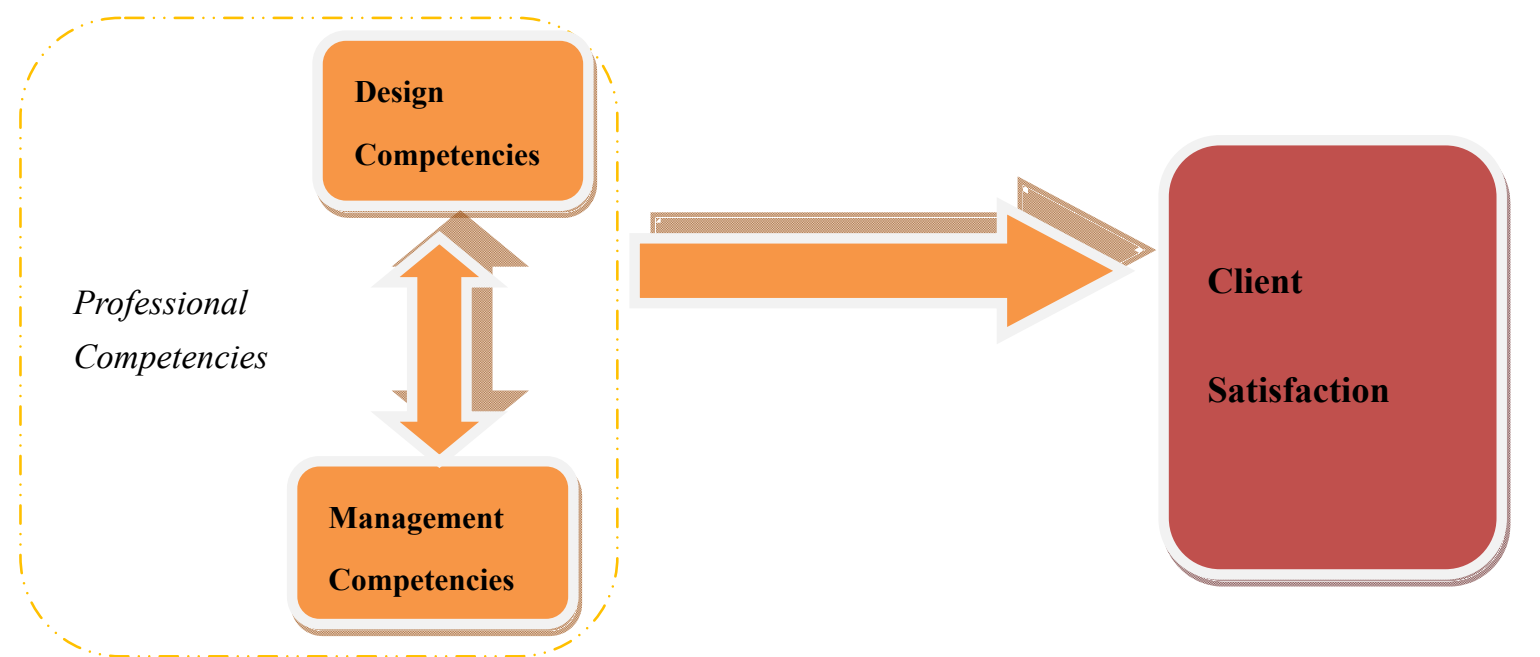

Figure 1. Conceptual model of the relationship between architects professional competencies and client satisfaction

In seeking to meet the objective of this study, the literature reviewed and the apparent gap in knowledge identified, the research question postulated is:

Research Question: Which architects' competency behaviours potentially relate and influence client satisfaction level? 


\section{Methodology}

The study adopted a 16-item design and management competencies of the architect (Table 1) developed based on the theoretical and practical perspective of architectural practice in Ghana by Kwofie et al. (2014). Data was collected from 85 project team leaders in the Ghanaian construction industry to respond to a questionnaire survey by indicating their level of perceived influence of the design and management competencies of the architect in their project team on client satisfaction level by drawing on their experience in working with the architects on their projects. The choice of the questionnaire technique is supported by similar studies by Henderson (2004), Tang et al. (2003) and thus enhances validity and triangulation.

In measuring the relationship between the architects' professional competencies and client satisfaction level, the design and management competencies, linear multiple regression and Pearson correlation analysis were used. The multiple regression analysis was used to assess the influence of the design and management competencies as two index independent variables on the client satisfaction level as the dependent variable. The Pearson correlation analysis was also used to identify the extent to which each of the design and management competencies in Table 1 relate to the client satisfaction level. A total of eighty five (85) project team leaders who have engaged and/or worked with architects on building projects were reached from the Ghanaian construction industry. Out of this, a total of 48 questionnaires were retrieved representing a response rate of $56 \%$. The results of the survey are presented in the following sections.

Table 1. Operationalized measures (dependent and independent variables) for the questionnaire

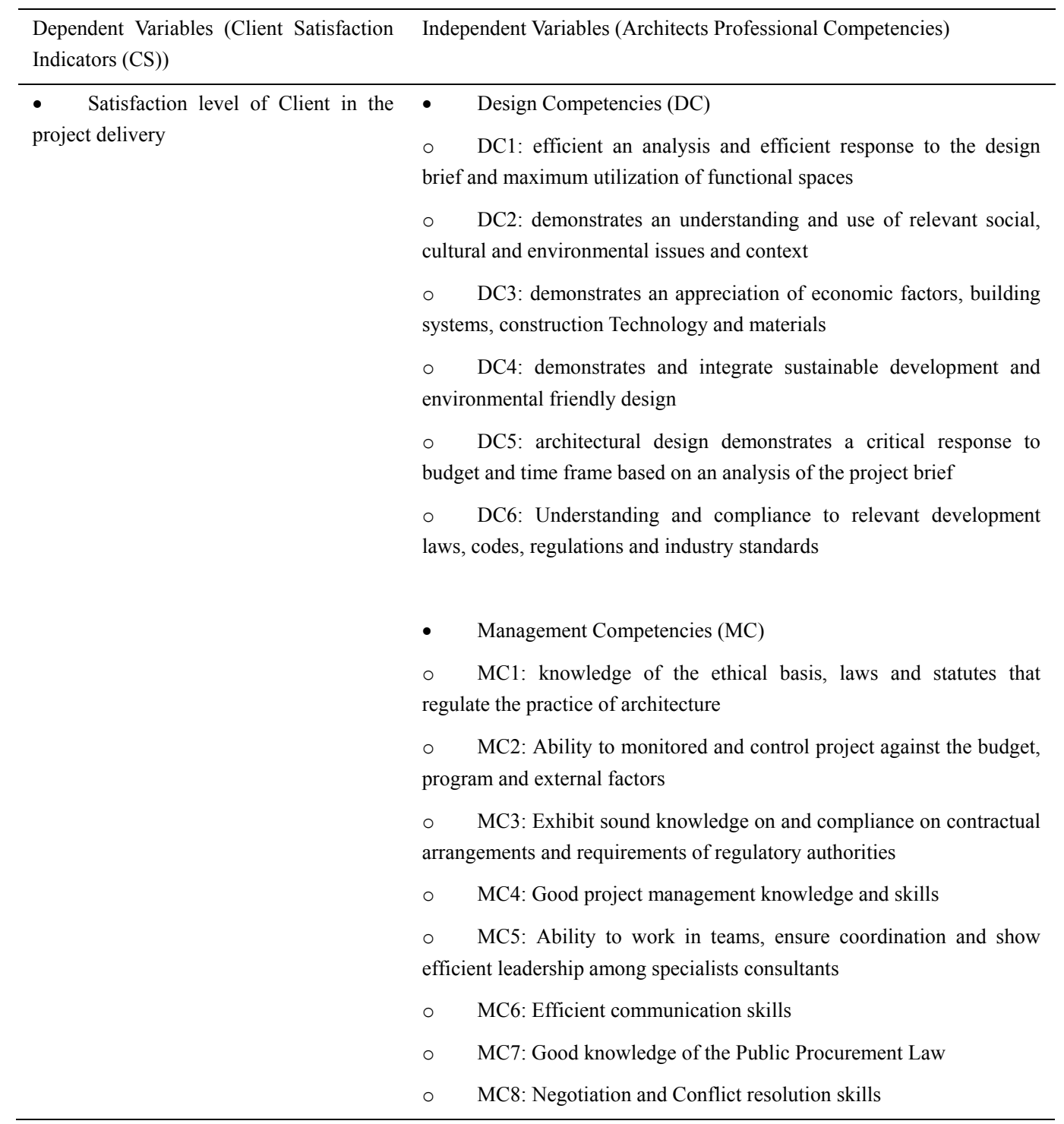




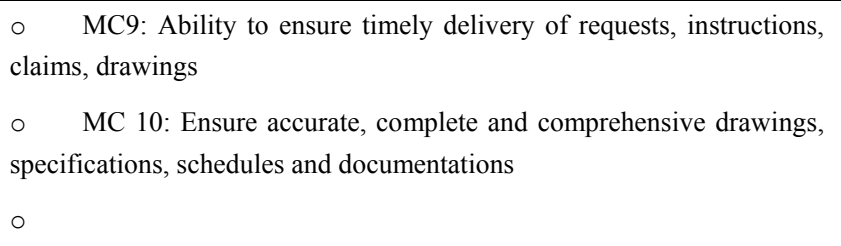

Source: Kwofie et al., (2014)

\section{Results and Discussions}

\subsection{Background of Respondents}

Table 2 shows the general characteristics of the project team leaders reached in the survey.

Table 2. Professions of project team leaders

\begin{tabular}{lll}
\hline Profession of Project Team Leader & Frequency & Percentage \\
\hline Project Managers & 15 & 31 \\
Quantity Surveyors & 8 & 17 \\
Engineers & 6 & 13 \\
Architect & 19 & 39 \\
TOTAL & 48 & 100 \\
\hline
\end{tabular}

From the 48 project team leaders who responded to the questionnaire survey, the composition of their professions was: project managers (31\%), Quantity Surveyors (17\%), Engineers (13\%) and Architects (39\%) as indicated in Table 2.

\subsection{Multiple Regression and Pearson Correlation Analysis}

The multiple regression analysis was deployed to measure the influence of the design and management competencies on the variance in client satisfaction outcome. The stepwise approach was conducted denoting the client satisfaction as the dependent variable against the design and management competencies as independent variables. The choice of stepwise regression was motivated by the fact that each of the design and management competencies was considered potentially useful and must all be tested to give an exploratory assessment of each variable (Field, 2005). The Pearson correlation was thus used to identify the nature and extent the design and management competencies significantly associate with the client satisfaction level as it is considered very robust over other correlation measures such as Spearman's rank correlation (Field, 2005). The results of the stepwise regression and Pearson Correlation which were conducted on the responses from the survey are presented in Table 3 and 4.

Table 3. Summary of results of stepwise regression of design and management competencies on client satisfaction

\begin{tabular}{llllll}
\hline Step & Variable & $\beta$ & $\mathrm{R}^{2}$ & $\Delta \mathrm{r}^{2}$ & Sig. \\
\hline 1 & Design (DC) & 0.801 & $0.391^{*}$ & - & 0.000 \\
2 & Design (DC) & 0.682 & & & 0.003 \\
3 & Management (MC) & 0.514 & $0.586^{*}$ & $0.195^{*}$ & 0.048
\end{tabular}

a. Dependent Variable: CLIENT SATISFACTION

$N=48 ; * p<0.05$ 
In multiple regression, it is accounted that the $\mathrm{R}^{2}$ values shows how good a prediction of the overall client satisfaction under this study can be deduced from the known predictor variables (architects' design and management competencies) in the optimum model (Field, 2005). Hence an $\mathrm{R}^{2}$ values that lies between 0.6 $\left(\mathrm{R}^{2}=36 \%\right)$ and $0.8\left(\mathrm{R}^{2}=64 \%\right)$ are described to have strong relationship among the predictor and criterion variables respectively (Field, 2005). From the summary of stepwise regression indicated in Table 3, design and management competencies were both retained in the regression equation with an $\mathrm{R}^{2}$ value of $58.6 \%(\bumpeq 59 \%)$ recorded, thus suggesting that the correlation lies between 0.6 and 0.8 . This can be described as depicting a strong relationship among the design and management competencies (predictor) and client satisfaction level (criterion) variables contained in the optimum model.

The summary of results of the stepwise multiple regression analysis of the design and management competencies on the client satisfaction represented in Table 3 indicated that both Design and Management competencies together significantly influence client satisfaction level of architects' product outcome. The Design competencies accounted for the highest $\beta$-value of 0.801 . Also, the $\beta$-value for Management competencies was 0.514 . In explaining this, it can be said that $39 \%$ of the variance $(p<0.05)$ in the client satisfaction level are influenced by architects' consulting services specifically determined by the professional design competencies. Subsequently, by combining with the management competencies (see Table 3), 59\% of the client satisfaction level can be influenced by both the architects' design and management competencies. Hence, the management competencies alone account for $\bumpeq 20 \%$ of the variance in client satisfaction.

Also, from the result of the Pearson's correlation analysis reported in Table 4, seven (7) of the professional competencies show significant correlation (2-tailed at $p<0.01$ and 0.05$)$ with the client satisfaction level. This contains four design competencies and six management competencies. The competencies are: "efficient analysis and efficient response to the design brief and maximum utilization of functional spaces (.592), demonstrates and integrate sustainable development and environmental friendly design (.456), architectural design demonstrates a critical response to budget and time frame based on an analysis of the project brief (.598), understanding and compliance to relevant development laws, codes, regulations and industry standards (.427), Good project management knowledge and skills (.575), Ability to work in teams, ensure coordination and show efficient leadership among specialists consultants (.424) and Ensure accurate, complete and comprehensive drawings, specifications, schedules and documentation (.408)."

Table 4. Correlation coefficients between architects' professional competencies and client satisfaction

\begin{tabular}{|c|c|}
\hline Professional Competencies & Client Satisfaction Level Correlation (sig.) \\
\hline $\begin{array}{l}\text { DC1: Efficient an analysis and efficient response to the design brief and maximum } \\
\text { utilization of functional spaces }\end{array}$ & $.592 * *($ sig value $=.001), N=48$ \\
\hline $\begin{array}{l}\text { DC2: Demonstrates an understanding and use of relevant social, cultural and } \\
\text { environmental issues and context }\end{array}$ & $.138($ sig value $=.452), \mathbf{N}=\mathbf{4 8}$ \\
\hline $\begin{array}{l}\text { DC3: Demonstrates an appreciation of economic factors, building systems, } \\
\text { construction Technology and materials }\end{array}$ & .332 ( sig value $=.055), \mathbf{N}=\mathbf{4 8}$ \\
\hline $\begin{array}{l}\text { DC4: Demonstrates and integrate sustainable development and environmental } \\
\text { friendly design }\end{array}$ & $.456 * *$ (sig. value $=.021), \mathrm{N}=48$ \\
\hline $\begin{array}{l}\text { DC5: Architectural design demonstrates a critical response to budget and time } \\
\text { frame based on an analysis of the project brief }\end{array}$ & $.598 * *$ (sig. value $=.000), \mathrm{N}=48$ \\
\hline $\begin{array}{l}\text { DC6: Understanding and compliance to relevant development laws, codes, } \\
\text { regulations and industry standards }\end{array}$ & $.427 *($ sig. value $=.012), \mathrm{N}=48$ \\
\hline $\begin{array}{l}\text { MC1: Knowledge of the ethical basis, laws and statutes that regulate the practice of } \\
\text { architecture }\end{array}$ & -.254 (sig. value $=.148), \mathrm{N}=48$ \\
\hline $\begin{array}{l}\text { MC2: Ability to monitored and control project against the budget, program and } \\
\text { external factors }\end{array}$ & .201 (sig. value $=.061$ ), $\mathrm{N}=48$ \\
\hline $\begin{array}{l}\text { MC3: Exhibit sound knowledge on and compliance on contractual arrangements } \\
\text { and requirements of regulatory authorities }\end{array}$ & -.265 (sig. value $=.130$ ), $\mathrm{N}=48$ \\
\hline MC4: Good project management knowledge and skills & $.575^{* *}($ sig. value $=.000), N=48$ \\
\hline
\end{tabular}


MC5: Ability to work in teams, ensure coordination and show efficient leadership

$.424 *$ (sig. value $=.004), \mathrm{N}=48$

among specialists consultants

MC6: Efficient communication skills

.244 (sig. value $=.083), \mathrm{N}=48$

MC7: Good knowledge of the Public Procurement Law

.158 )sig. value $=.372), \mathrm{N}=48$

MC8: Negotiation and Conflict resolution skills

$.108($ sig. value $=.545), \mathrm{N}=48$

MC9: Ability to ensure timely delivery of requests, instructions, claims, drawings

-.102 (sig. value $=.094), \mathrm{N}=48$

MC10: Ensure accurate, complete and comprehensive drawings, specifications, schedules and documentations

*Correlation is significant @ the 0.05 level (2-tailed)**Correlation is significant @ the 0.01 level (2-tailed)

\subsection{Discussion of Results}

The findings show a significant positive relationship between architects' design and management competencies and client satisfaction level. As recorded in Table 3, Architects' design and management competencies significantly influence and relate to $58.6 \%$ of the variance in client satisfaction level in construction project delivery. Design competencies account for the largest proportion of the relationship at $39.1 \%$. The management competencies significantly accounts for $\bumpeq 20 \%$ of the variance in client satisfaction of architects' professional consulting services.

The "efficient an analysis and efficient response to the design brief and maximum utilization of functional spaces"showed a significant relationship with client satisfaction $(\mathrm{r}=.592, p$ (two tailed $)<0.01)$. This supports Ling (2003) that architects ability to perform to meet the design needs of client are critical in their selection onto project teams by project managers and clients. According to Cheung et al. (2002), a good and efficient design by architects must in addition to performing aesthetic satisfaction to client also additionally ensure social, cultural and economic quality of the built environment now and in the future. This shows that efficient design is very crucial to meeting client satisfaction in the Ghanaian construction industry. Hence, this finding has important implications for the roles of architects in project delivery in meeting client needs and their design task functions in multi and cross functional project teams which are common in project delivery in the Ghanaian construction industry.

The finding "demonstrate and integrate sustainable development and environmental friendly design" and "architectural design demonstrates a critical response to budget and time frame based on an analysis of the project brief" showing strong relationship with client satisfaction level (see Table 4.) highlight the relevance of sustainable development and delivering projects on time and cost to client as critical factors. A study by Ahadzie and Badu (2011) investigating success criteria for house building in Ghana established that a design response that emphasis adequate natural ventilation and thermal comport is critical to the success of their houses. Given the current state of energy crisis in Ghana coupled with high tariffs in electricity, developing skills of architect to deliver sustainable and environmentally friendly designs to better meet the needs of their client is crucial. Subsequently, it is affirmed that success at the construction stage in project delivery depends on efficient design process and management at the design phase hence developing efficient design competencies are extremely crucial (Ahadzie et al., 2014). Additionally, Liu and Walker (1998) also emphasized that client satisfaction is an attribute of project success and thus attainment of project within budgets, on time and highest quality is crucially important. Traditionally, in the Ghanaian construction industry, delivering projects on time and on budget at the highest quality is considered as an impetus to client satisfaction level (Ahadzie \& Badu, 2011). Against this background, architects must ensure the delivery of design options at the most acceptable budget that supremely meet their needs and expectation.

Efficient leadership skills and coordination among project team is considered as an essential ingredient towards team effectiveness in construction project delivery (Takim \& Adnan, 2008). Drawing on the theoretical and practical perspective of the construction industry in Ghana makes the emergence of "ability to work in teams, ensure coordination and show efficient leadership among specialists consultants"all the more crucial. The study revealed that this competency significantly associate to the client satisfaction level. In Ghana, the traditional procurement concept where the architect leads the project team remains the most dominant concept in project delivery. In the light of this, the emergence of this skill is very much relevant to the training and development of the architectural profession especially in Ghana. In the industry, the project team leader must provide direction, motivation, the drive and leadership necessary to steer the project to success by successfully integrating the 
functions of all team members. Given that the supply chain among construction participants are highly adversarial in Ghana (Orgen et al., 2013), the significance of this competency is thus very important in ensuring a cohesive team to successfully deliver client needs satisfaction.

Also, "good project management knowledge and skills" emerged to have a significant correlation with client satisfaction as seen in Table 4 ( $\mathrm{r}=.575, p$ (two tailed) $<0.01)$. This offers a meaningful contribution to literature. It emphasizes the importance of the project management (PM) to project delivery as well as affirming the need for architects to further and continuously embrace, develop and improve their knowledge in PM practices in the Ghanaian industry. Bresnahan (2000) identified project management knowledge and skills as the critical current training needs of built environment professionals in order to increase project delivery successes and thus the architects' most suitability for project leadership makes the knowledge and skills in requisite areas of project management extremely important (Odusami, 2003).

Fugar and Agyakwah-Baah (2010) established that discrepancies between designs, specifications and building codes is a major challenge causing continued delays on projects and remains a serious element of disputes in the Ghanaian construction industry. Xie (2002) further determined that sharing of accurate and complete information related to the design is critical to successful project delivery among the design team. Hence, the identification of "Ensure accurate, complete and comprehensive drawings, specifications, schedules and documentations" as significantly influencing client satisfaction makes it very imperative for architects in the Ghanaian industry. This is premised on the theoretical position that traditionally, the architects design is seen as the primary data for all documentations and production drawings and as such it is crucial to achieve the highest form of accuracy, completeness and clarity to engender the needed understanding by all participants towards success in the project delivery.

Conversely, a more careful and thorough examination of the findings reveal that interestingly the variables "exhibit sound knowledge on and compliance on contractual arrangements and requirements of regulatory authorities", "efficient communication skills", "good knowledge of the Public Procurement Law", "ability to ensure timely delivery of requests, instructions, claims, drawings" and "negotiation and conflict resolution skills" had no significant correlation with client satisfaction. Perhaps a plausible explanation could be that all these competencies are embedded in project management practices and thus a competency in project management will encompass all these skills. Hence it could be summed that as architects enhance their knowledge in project management practice they also embrace these variables to better impact their client satisfaction level.

\section{Conclusion and Recommendation}

It is emphasised that success of a consulting firms depend on their ability to satisfy client and that is crucial for its survival and expansion. This study has revealed that the design competencies of architects relate to $39 \%$ of clients satisfaction whiles their management competencies are able to influence approximately $20 \%$ of their satisfaction level. The pearson correlation analysis has also revealed seven (7) design and management competencies of architects that show significant relationship between architects professional competencies and client satisfaction level. Significant positive relationship was revealed between four design competencies and three management competencies (see Table 4). Hence it can be concluded that architects professional competencies relate to the client satisfaction level on the product outcome delivered by architects and this adequately answers the research question.

From the results, it can be stressed that the findings make important contribution to understanding the relationship between client satisfaction and competency development. It can be deduced that by architects focusing and improving on these skills that relate to client satisfaction level, they can influence about $59 \%$ of their client satisfaction in project delivery in the Ghanaian construction industry and that is crucial for their professional practice. Hiring competent professional architects remains the foremost success factor that crucially relate to project success and meeting client needs in the service based organisations and firms. In the light of this, a very significant recommendation from the study is for architects to continue to develop and embrace these skills to better serve and maintain their clients in the industry. Subsequently, although the findings are just valid for the Ghanaian industry, it also has the potential of offering valuable reference for many developing countries especially in sub-Saharan Africa with similar professional training and practice in architecture and construction project delivery. The findings are also very useful for future training and continuous professional development of architects in Ghana. It is further recommended that further studies are conducted on these skills by focusing of the various phases of the project delivery cycle.

\section{Reference}

AACA. (2008). The national competency standards in architecture. Retrieved November 6, 2013, from 
http://www.austlii.edu.au/au/legis/cth/consol_aqct/ca1968133

Ahadzie D., Proverbs D., \& Sarkodie-Poku, I. (2014). Competencies required of Project Managers at the design phase of mass housing building projects. International Journal of Project Management, 32(6), 958-969. http://dx.doi.org/10.1016/j.ijproman.2013.10.015

Ahadzie, D. K., \& Amoa-Mensa, K. (2010). Management Practices in Ghanaian House Building Industry. Journal of Science and Technology, 30(2), 62-75.

Ahadzie, D. K., \& Badu, E. (2011), Success indicators for selfbuild house in two Ghanaian cities. Journal of Science and Technology, 31(3), 86-96.

Alvesson, M. (2001). Social identity and the problem of loyalty in knowledge-intensive companies. In F. Blackler, D. Courpasson, \& B. Elkjaer (Eds.), Knowledge Work, Organisations and Expertise: European Perspectives (pp. 582-587). Routledge, London.

Bennett, R., Charmine, E. J. H., \& McColl-Kennedy, J. R. (2005). Experience as a moderator of involvement and satisfaction on brand loyalty in a business-to-business setting. Industrial Marketing Management, 34(1), 97-107. http://dx.doi.org/10.1016/j.indmarman.2004.08.003

Biemans, H., Nieuwenhuis, L., Poell, R., Mulder, M., \& Wesselink, R. (2004). Competence-based VET in the Netherlands: Background and pitfalls. Journal of Vocational Education and Training, 56(4), 523-538. http://dx.doi.org/10.1080/13636820400200268

Bresnahan, K. M. (2000). Core Competencies for Project Managers Implementing Financial Systems in the Federal Government. Retrieved Nov 11, 2013, from http://www.jfmip.gov

Cheung, F. K. T., Kuen, J. L. F., \& Skitmore, M. (2002). Multi-criteria evaluation model for the selection of architectural consultants. Construction Management and Economics, 20(7), 569-580. http://dx.doi.org/10.1080/01446190210159818

Day, E., \& Barksdale, H. C. (2003). Selecting professional service provider from the short list. Journal of Business \& Industrial Marketing, 18(6/7), 564-579. http://dx.doi.org/10.1108/08858620310492428

Escrig-Tena A. B., \& Bou-Llusar J. C. (2005). A Model for Evaluating Organizational Competencies: An Application in the Context of a Quality Management Initiative. Decision Sciences, 36(2), 221-257. http://dx.doi.org/10.1111/j.1540-5414.2005.00072.x

Field, A. (2005). Discovering Statistics Using SPSS for Windows. London Sage Publications.

Fugar, F. D. K., \& Agyarkwa-Baah, A. (2010). Delays in building Construction in Ghana. Aust. J. of Const. Econs. and Building, 10(1/2), 103-116.

Gottlieb, J. B., Grewal, D., \& Brown, S. W. (1994). Consumer satisfaction and perceived quality: Complementary or divergent constructs. Journal of Applied Psychology, 79(6), 875-885. http://dx.doi.org/10.1037/0021-9010.79.6.875

Haverila, M, Bateman, E. R., \& Naumann, E. R. (2011). The drivers of customer satisfaction in strategic consulting engagements: A global study. Management Decision, 49(8), 1354-1370. http://dx.doi.org/10.1108/00251741111163160

Henderson, L. S. (2004). Encoding and decoding communication competencies in project management-An exploratory study. International Journal of Project Management, 22, 469-476. http://dx.doi.org/10.1016/j.ijproman.2004.01.004

Kwofie, T. E., Amos-Abanyie, S., \& Opoku, D. (2014). Critical Professional Competencies of Architects in the Ghanaian Construction Industry. International Journal of Architecture, Engineering and Construction, 3(2), 24-32.

Ley, T., \& Albert, D. (2003). Identifying Employee Competencies in Dynamic Work Domains: Methodological Considerations and a Case Study. Journal of Universal Computer Science, 9(12), 1500-1518.

Ling, Y. Y. (2003). A conceptual model for the selection of architects by project managers in Singapore. $\begin{array}{llll}\text { International Journal of Project } & \text { Management, } & \text { 21, }\end{array}$ http://dx.doi.org/10.1016/S0263-7863(02)00014-5

Liu, A. M. M., \& Walker, A. (1998). Evaluation of project outcomes. Construction Management and Economics, 16(2), 209-219. http://dx.doi.org/10.1080/014461998372493

Moore, D. R., Cheng, M., \& Dainty A. R. (2002). Competence, competency and competencies: Performance 
assessment in organisations. Work Study, 51(6), 314-319. http://dx.doi.org/10.1108/00438020210441876

Ng, S. T., \& Chow, L. (2004). Framework for Evaluating the Performance of Engineering Consultants. Journal of Professional Issues in Engineering Education and Practice, 130(4), 280-288. http://dx.doi.org/10.1061/(ASCE)1052-3928(2004)130:4(280)

Odusami, K. T. (2003). Criteria for measuring project performance by construction professionals in Nigerian construction industry. Journal of Financial Management of Property and Construction, 8(1), 39-48.

Ofori, G. (1999). Satisfying the customer by changing production patterns to realise sustainable construction. Proceedings of Joint Triennial Symposium of CIB Commissions W65 and 55, 1, 41-56.

Orgen, N. K., Ahadzie, D. K., Ayarkwa, J. \& Badu, E. (2012). An integrated Supply Chain Relationship Management theoretical framework for improving Engineering and Design Service Delivery (EDSD) to Building Contractors in Ghana. In S. Laryea, S. A. Agyepong, R. Leiringer, \& W. Hughes (Eds.), Procs 4th West Africa Built Environment Research (WABER) Conference (pp. 1-7). 24-26 July 2012, Abuja, Nigeria.

Pickett, L. (1998). Competencies and managerial effectiveness: Putting competencies at work. Public Personnel Management, 27(1), 103-115.

Prastacos, G. P., Soderquist, K. E., \& Vakola, M. (2005). A Strategic Forward-Looking Approach to Competency Modelling. Business Leadership Review, 2, 1-5.

RIBA Plan of Work. (2013). Consultation document. Retrieved Dec 6, 2013, from https://www.surveymonkey.com/s/V73WCS6

Tang, S., Lu, M., \& Chan, Y. (2003). Achieving Client Satisfaction for Engineering Consulting Firms. Jounal of $\begin{array}{llll}\text { Management } \quad \text { Endineering, 166-172. } & \text { 19(4), }\end{array}$ http://dx.doi.org/10.1061/(ASCE)0742-597X(2003)19:4(166)

Takim, R., \& Adnan, H. (2008). Analysis of Effectiveness Measures of Construction Project Success in Malaysia. Asian Social Science, 2(7), 74-91.

Torbica Z. M., \& Stroh R. C. (2001). Customer satisfaction in home building. Journal of Construction Engineering and Management, 127(1), 82-96. http://dx.doi.org/10.1061/(ASCE)0733-9364(2001)127:1(82)

UIA. (1999). Accord on Recommended International Standards of Professionalism in Architectural Practice. Retrieved Nov 5, 2014, from http://www.di.net/articles/professionalism-andethics-in-architectural-education/

Xie, X. (2002). Communications in Construction Design. A Doctor of Philosophy Thesis of Loughborough University. Retrieved Nov 6, 2012, from https://dspace.lboro.ac.uk/

Yang, S., \& Zhu, Y. (2006). Customer Satisfaction Theory Applied in the Housing Industry: An Empirical Study of Low-Priced Housing in Beijing. Tsinghua Science \& Technology, 11(6), 667-674. http://dx.doi.org/10.1016/S1007-0214(06)70249-8

Yang J., \& Peng, S. (2006). Development of a customer satisfaction evaluation model for construction project management. Building and Environment, 43, 458-468. http://dx.doi.org/10.1016/j.buildenv.2006.07.044

\section{Copyrights}

Copyright for this article is retained by the author(s), with first publication rights granted to the journal.

This is an open-access article distributed under the terms and conditions of the Creative Commons Attribution license (http://creativecommons.org/licenses/by/3.0/). 